\title{
The Relationship between Anxiety, Depression, and Problematic Internet Use among a Sample of university students in Egypt
}

\author{
Safeya Mahmoud Ahmed Effat*, Hemaid Mustafa Azab**, Hanan Yousef \\ Aly***,Osama Abd Alreheem Mahmoud****. \\ * Professor of Psychiatry- faculty of medicine-Ain Shams University \\ ** Professor of Neuropsychiatry- faculty of medicine-Sohag University \\ **** Lecturer of Neuropsychiatry- faculty of Medicine-Sohag University \\ ****Assistant Lecturer of Neuropsychiatry -faculty of Medicine-Sohag University
}

\begin{abstract}
Objective:Problematic Internet Use (PIU) is a growing problem among adolescents. This study was designed to investigate the prevalence of PIU and to explore the relationship between anxiety, depression , and PIU among sample of Egyptian university students.

Methods:A cross-sectional survey was conducted from February 2017 to January 2018on a random sample of 588 students selected from four faculties in Sohag University. PIU was assessed by the 20-item Young Internet Addiction Test (YIAT). Information was also collected on demographics, family and school-related factors and Internet usage patterns. Taylor's Manifest Anxiety Scale was used as a general indicator of anxiety.Beck depression inventorywas used for measuring the existence and the severity of depression.

Results: Findings showed that the prevalence of PIU among the studied population was $35.2 \%$.About $86.9 \%$ of Students with PIU significantly had anxietyalso, $85.02 \%$ of Students with PIU significantly had Depression . Depression, Availability of internet at home, Anxiety,presence of computer at home, using Internet for chatting, high monthly income, young age, Theoretical faculties , using Internet for chatting and Male gender were the most important predictors of PIU. Conclusion:PIU prevalent disorder among undergraduate university studentsin Egypt. Clinicians and health professionals should be aware of the risk of PIUin students with Anxiety and Depression.
\end{abstract}

Keywords: Problematic Internet Use; prevalence;Depression; Anxiety

\section{INTRODUCTION}

The use of the internet to achieve a desired goal within an appropriate period of time without intellectual or behavioral discomfort is called Healthy use of the internet ${ }^{[1]}$ Excessive internet use, which is also called pathological internet use, internet addiction, leads to problems in work and social life ${ }^{[2]}$ Internet addiction can be defined as a maladaptive pattern of internet use leading to clinically significant impairment or distress ${ }^{[3]}$ The prevalence of internet addiction range from $0.3 \%$ to $38 \%$ in many studies, and this discrepancy might be due methodological variation in diagnosis and diversity in use of diagnostic instruments ${ }^{[4]}$ Internet addiction found to be associated with anxiety disorders ${ }^{[5,6]}$ and depression in young people $\cdot{ }^{[7]}$ Internet addiction among depressive patients has similar incidence of depression among individuals with internet addiction ${ }^{[7]}$ Depression has many manifestation as deep sorrow or grief, insomnia, loss of appetite, unpleasant mood, hopelessness, irritability, self-dislike, 
and suicidal tendencies, low selfesteem, low motivation, fear of rejection and the need for confirmation from others ${ }^{[8]}$ all of which may result in frequent use of the internet, and the interactive functions of the internet may lead to internet addiction in individuals with these characteristics $\quad{ }^{[9]}$ Previous reports demonstrated that anxiety, ADHD, and depression are the 3 psychological disorders that are prevalent in individuals with internet addiction $\cdot{ }^{[10]}$ Also, other researchers have found that shyness and social anxiety are significant predictors of internet addiction ${ }^{[7,11,12]}$ In another study, ${ }^{[13]}$ it was found that an individual suffering from anxiety symptoms may seek companionship in a safe cyberspace.

\section{METHOD:}

Study design:A cross-sectional survey was conducted from February 2017 to January 2018.

Site of study:Sohag University is an independent University that includes fourteen faculties among them four Faculties (Faculty of Veterinary Medicine, Faculty of Science, Faculty of Commerce and Faculty of Arts) were chosen to be involved in the current study.

\section{Study participants and sampling:}

The sample size was calculated to be 600 students as calculated using Open EPI program based on the following assumptions: Prevalence of Internet addiction is $13 \%$ according to the results of a previous study conducted in Menofia university ${ }^{[14]}$, power as $80 \%$, response distribution as $50 \%$, while confidence interval and margin of error were set at $99.9 \%$ and $0.1 \%$, respectively. By Using a multistage clustering sampling method, we selected the students for our study as follows: The first stage:Two practical faculities (faculty of Veterinary Medicine and faculty of
Science) and Two theoretical faculities (faculty of Arts and faculty of Commerce) were choosen from Sohage university following simple random sampling technique.The second stage: The sample size divided on both practical and theoretical faculities with 400 students from theoretical faculities and 200 students from practical faculities according to stratified cluster random sampling technique. The third stage:The students were selected by rondom cluster sampling method as follows :100 students from faculty of Veterinary Medicine 50 students in the $1^{\text {st }}$ stage and 50 students in the last stage, 100 students from faculty of Science 50 students in the $1^{\text {st }}$ stage and 50 students in the last stage, 200 students from faculty of Commerce 100 students in the $1^{\text {st }}$ stage and 100 students in the last stage, 200 students from faculty of Arts 100 students in the $1^{\text {st }}$ stage and 100 students in the last stage. 12 students were excluded on the basis of incomplete questionnaires and the study included 588 students.

Inclusion criteria:Sohage university students of the following faculities:Faculty of Veterinary Medicine, Faculty of Science, Faculty of Commerce and Faculty of Arts.Age 18 years old or more.Sex: both sexes were included.

\section{Study instrument}

All students were subjected to the following procedures:

1-Self- administered questionnaire for Assesment of; Socio-demographic and academic data of the student (age,sex, residence, average monthly family income and father job), Patterns of internet use(Type of internet activity, presence of computer at house and presence of internet at house).

2-Assesment of the degree of internet addiction: By using Young internet 
SOHAG MEDICAL JOURNAL

Vol. 23 No.1 Jan 2019

addiction test ${ }^{[15]}$ We used the Arabic version translated byHawi. ${ }^{[16]}$ The IAT includes 20 items, each of which is rated on a six-point Likert scale.It has ascore range from 0 to 100 Normal internet usage $(0-19)$,mild internet usage $(20-49)$,moderate internet usage $(50-79)$ and sever or excessive internet usage $(80$ - 100).In our study The following cut-off points were applied to the total YIAT score:Normal Internet use or non problematic Internet use : scores 0-49 and Potential problematic Internet use (PIUs): scores equal or over 50

3-Taylor's Manifest Anxiety Scale (TMAS) ${ }^{[17]}$ : As a general indicator of anxiety as a personality trait. We used the Arabic version translated byFahmi et al. ${ }^{[18]}$ It consisted of 50 true or false questions a person answers by reflecting on themselves, in order to determine their anxiety level.It has Score range from 0 to 50: no anxiety (0 -16 ), mild anxiety (17- 24), moderate anxiety (25-35) and sever anxiety (36 -50).

4-Beck depression inventory ${ }^{[19]}$ : For measuring the existence and the severity of depression. We used the Arabic version translated byAbdelKhalek. ${ }^{[20]}$ It is 21 -question multiple-
The Relationship between Anxiety

Osama Abd Alreheem Mahmoud.et al

choice self-report inventory.It has Score range from 0 to 63 :normal(0 13), mild depression(14 - 19), moderate depression(20 - 28) and sever depression(29-63).

\section{Ethical consideration:}

Before starting data collection, ethical approval was obtained from Scientific Research Ethical Committee of the faculty of medicine, Sohag University. Additionally, official approval from Deans of the fourstudied Faculties was secured. An informed consent was obtained from each participant prior to filling the questionnaires.

\section{The statistical analysis:}

The data were coded, tabulated and analyzed using [SPSS] version 20 . Qualitative data were expressed as numbers and percentages, and the Chisquare test were applied to test the relationship between variables. Quantitative data were expressed as mean and standard deviation (Mean \pm $\mathrm{SD})$ and t- test were used to compare means for groups. Pearson correlation test were applied to test the relationship between quantitative variables. A pvalue of $<0.05$ were considered as statistically significant.

\section{RESULTS}

The current study included 588 students, 196 student from Two practical faculties (faculty of Veterinary Medicine and faculty of Science) and 392 students from Two theoretical faculties (faculty of Arts and faculty of commerce). The mean age of students was $20.18 \pm 1.50$, with equal number of females and male students ,number of urban students were more than rural students (Table 1).Nearly one third of the students were PIU and two thirds were normal internet users (Figure 1). Students of theoretical facultiessignificantly had Potentialy problematic internet use (PIU) thanStudents of practical faculties (Figure 2). PIU significantly more in younger age ,Male students. Fathers ofPIU students significantly had employed jobs.PIU significantly higher in students with high monthly income (Table 2). PIU significantly more in theoretical faculties than in practical faculties. Students with PIUsignificantly had computer and internet at homeand used internet in chatting and games (Table 3). $86.96 \%$ of Students with PIU significantly had anxiety (Table 4). and $85.02 \%$ of Students with PIUsignificantly had depression (Table 5). 


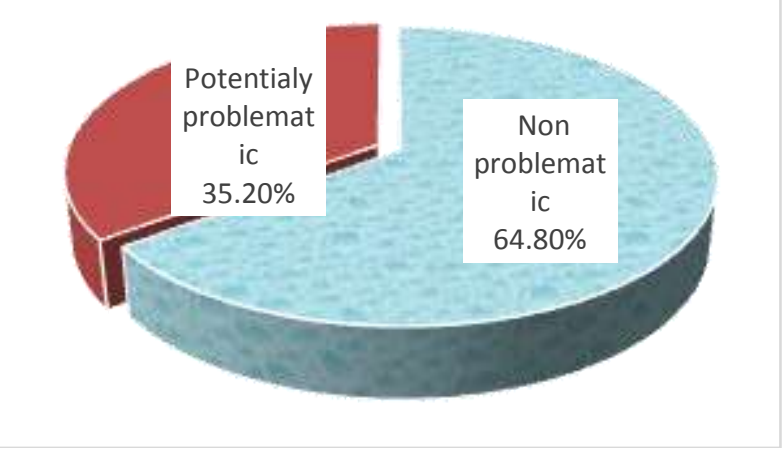

Figure (1): Distribution of studied students according to internet addiction.

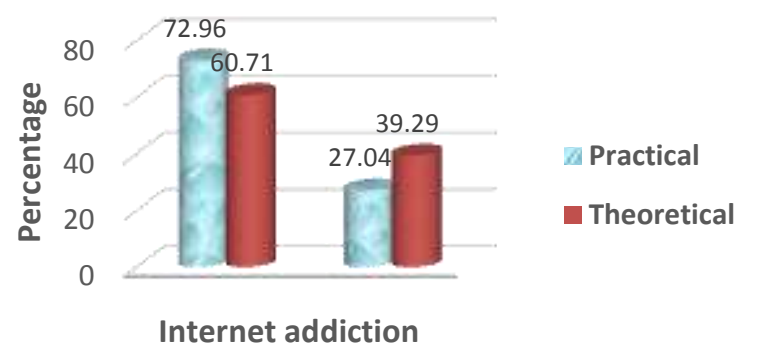

Figure (2): Distribution of internet addiction among students of practical and theoretical faculties.

\begin{tabular}{|c|c|c|}
\hline $\begin{array}{c}\text { Socio- } \\
\text { demographic }\end{array}$ & number & Percentage \% \\
\hline $\begin{array}{l}\text { Age/years } \\
\text { Mean } \pm \text { SD }\end{array}$ & $20.18 \pm 1.50$ & \\
\hline $\begin{array}{l}\text { Gender } \\
\text { Females } \\
\text { Males } \\
\end{array}$ & $\begin{array}{l}294 \\
294\end{array}$ & $\begin{array}{l}\mathbf{5 0 . 0 0 \%} \\
\mathbf{5 0 . 0 0 \%}\end{array}$ \\
\hline $\begin{array}{l}\text { Residence } \\
\text { Rural } \\
\text { Urban } \\
\end{array}$ & $\begin{array}{l}259 \\
329\end{array}$ & $\begin{array}{l}\mathbf{4 4 . 0 5 \%} \\
\mathbf{5 5 . 9 5 \%}\end{array}$ \\
\hline $\begin{array}{l}\text { Father job } \\
\text { Farmer } \\
\text { Official } \\
\text { employed } \\
\text { Self employed } \\
\text { Retired }\end{array}$ & $\begin{array}{c}71 \\
274 \\
142 \\
101\end{array}$ & $\begin{array}{l}12.07 \% \\
46.60 \% \\
24.15 \% \\
17.18 \%\end{array}$ \\
\hline $\begin{array}{l}\text { Monthly income } \\
\text { Less than } 2000 \\
2000-5000 \\
\text { More than } 5000\end{array}$ & $\begin{array}{l}171 \\
273 \\
144 \\
\end{array}$ & $\begin{array}{l}29.08 \% \\
46.43 \% \\
24.29 \%\end{array}$ \\
\hline
\end{tabular}

Table(1): Socio-demographic data of the students. 
SOHAG MEDICAL JOURNAL

Vol. 23 No.1 Jan 2019
The Relationship between Anxiety Osama Abd Alreheem Mahmoud.et al

\begin{tabular}{|c|c|c|c|c|c|}
\hline \multirow{2}{*}{$\begin{array}{l}\text { Socio- } \\
\text { demographic } \\
\text { data }\end{array}$} & \multicolumn{2}{|c|}{ non-problematic } & \multicolumn{2}{|c|}{ potentialy problematic } & \multirow{2}{*}{$P$ value } \\
\hline & $\mathrm{N}=381$ & Percentage\% & $\mathrm{N}=\mathbf{2 0 7}$ & $\begin{array}{l}\text { Percentage } \\
\%\end{array}$ & \\
\hline $\begin{array}{l}\text { Age/years } \\
\text { Mean } \pm \text { SD }\end{array}$ & $20.36 \pm 1.50$ & & $19.85 \pm 1.45$ & & $0.0001 * *$ \\
\hline $\begin{array}{l}\text { Gender } \\
\text { Females } \\
\text { Males } \\
\end{array}$ & $\begin{array}{l}223 \\
158 \\
\end{array}$ & $\begin{array}{l}\mathbf{5 8 . 5 3 \%} \\
\mathbf{4 1 . 4 7 \%} \\
\end{array}$ & $\begin{array}{c}71 \\
136\end{array}$ & $\begin{array}{l}34.30 \% \\
65.70 \% \\
\end{array}$ & $<0.0001 * *$ \\
\hline $\begin{array}{l}\text { Residence } \\
\text { Rural } \\
\text { Urban } \\
\end{array}$ & $\begin{array}{l}163 \\
218 \\
\end{array}$ & $\begin{array}{l}\mathbf{4 2 . 7 8 \%} \\
\mathbf{5 7 . 2 2 \%} \\
\end{array}$ & $\begin{array}{c}96 \\
111 \\
\end{array}$ & $\begin{array}{l}\mathbf{4 6 . 3 8 \%} \\
53.62 \% \\
\end{array}$ & $\mathbf{0 . 4 3}$ \\
\hline $\begin{array}{l}\text { Father job } \\
\text { Farmer } \\
\text { Official } \\
\text { employed } \\
\text { Self employed } \\
\text { Retired } \\
\end{array}$ & $\begin{array}{c}59 \\
149 \\
106 \\
67\end{array}$ & $\begin{array}{l}15.49 \% \\
39.11 \% \\
27.82 \% \\
17.59 \%\end{array}$ & $\begin{array}{c}12 \\
125 \\
36 \\
34\end{array}$ & $\begin{array}{l}5.80 \% \\
60.39 \% \\
17.39 \% \\
16.43 \%\end{array}$ & $0.0001 * *$ \\
\hline $\begin{array}{l}\text { Monthly income } \\
\text { Less than } 2000 \\
2000-5000 \\
\text { More than } 5000\end{array}$ & $\begin{array}{c}135 \\
188 \\
58\end{array}$ & $\begin{array}{l}35.43 \% \\
49.34 \% \\
15.22 \%\end{array}$ & $\begin{array}{l}36 \\
85 \\
86\end{array}$ & $\begin{array}{l}17.39 \% \\
41.06 \% \\
41.55 \%\end{array}$ & $<0.0001 * *$ \\
\hline
\end{tabular}

Table (2): Comparison between non-problematic and potentialy problematic internet user according to Socio-demographic data.

\begin{tabular}{|c|c|c|c|c|c|}
\hline \multirow{2}{*}{ Academic data } & \multicolumn{2}{|c|}{ non-problematic } & \multicolumn{2}{|c|}{ potentialy problematic } & \multirow[t]{2}{*}{$P$ value } \\
\hline & $\mathrm{N}=381$ & Percentage \% & $\mathrm{N}=\mathbf{2 0 7}$ & Percentage \% & \\
\hline $\begin{array}{l}\text { Faculty } \\
\text { Practical } \\
\text { Therotical } \\
\end{array}$ & $\begin{array}{l}143 \\
238 \\
\end{array}$ & $\begin{array}{l}37.53 \% \\
62.47 \% \\
\end{array}$ & $\begin{array}{c}53 \\
154 \\
\end{array}$ & $\begin{array}{l}25.60 \% \\
74.40 \% \\
\end{array}$ & $0.003 * *$ \\
\hline $\begin{array}{l}\text { Presence of } \\
\text { computer at home } \\
\text { Not present } \\
\text { Present }\end{array}$ & $\begin{array}{l}147 \\
234 \\
\end{array}$ & $\begin{array}{l}38.58 \% \\
61.42 \%\end{array}$ & $\begin{array}{c}42 \\
165\end{array}$ & $\begin{array}{r}20.29 \% \\
79.71 \% \\
\end{array}$ & $<0.0001 * *$ \\
\hline $\begin{array}{l}\text { Availability of } \\
\text { internet at home } \\
\text { Not present } \\
\text { Present }\end{array}$ & $\begin{array}{l}156 \\
225\end{array}$ & $\begin{array}{l}\mathbf{4 0 . 9 4 \%} \\
\mathbf{5 9 . 0 6 \%} \\
\end{array}$ & $\begin{array}{c}32 \\
175\end{array}$ & $\begin{array}{l}15.46 \% \\
84.54 \% \\
\end{array}$ & $<0.0001 * *$ \\
\hline $\begin{array}{l}\text { Main aim of } \\
\text { internet use } \\
\text { Chatting } \\
\text { Games } \\
\text { Gather information } \\
\text { News }\end{array}$ & $\begin{array}{c}74 \\
61 \\
144 \\
202 \\
\end{array}$ & $\begin{array}{l}19.42 \% \\
16.01 \% \\
37.80 \% \\
26.77 \% \\
\end{array}$ & $\begin{array}{l}87 \\
59 \\
31 \\
30\end{array}$ & $\begin{array}{l}42.03 \% \\
28.50 \% \\
14.98 \% \\
14.49 \% \\
\end{array}$ & $<0.0001 * *$ \\
\hline
\end{tabular}

Table(3): Comparison between non-problematic and potentialy problematic internet user regarding to Academic data and patterns of internet use 
SOHAG MEDICAL JOURNAL

Vol. 23 No.1 Jan 2019
The Relationship between Anxiety Osama Abd Alreheem Mahmoud.et al

\begin{tabular}{|l|c|c|c|c|c|}
\hline \multirow{2}{*}{$\begin{array}{l}\text { Taylor's Manifest } \\
\text { Anxiety Scale } \\
\text { (TMAS) }\end{array}$} & \multicolumn{2}{|c|}{ non-problematic } & \multicolumn{2}{|c|}{ potentialy problematic } & P value \\
\cline { 2 - 5 } & N=381 & Percentage \% & N=207 & Percentage \% & \\
\hline No Anxiety & $\mathbf{1 7 2}$ & $\mathbf{4 5 . 1 4 \%}$ & $\mathbf{2 7}$ & $\mathbf{1 3 . 0 4 \%}$ & \\
\hline Anxiety disorders; & $\mathbf{2 0 9}$ & $\mathbf{5 4 . 8 6 \%}$ & $\mathbf{1 8 0}$ & $\mathbf{8 6 . 9 6 \%}$ & \\
\hline Mild & 119 & $31.23 \%$ & 27 & $13.04 \%$ & \\
$\begin{array}{l}\text { Moderate } \\
\text { Sever }\end{array}$ & 81 & $21.26 \%$ & 103 & $49.76 \%$ & \\
\hline
\end{tabular}

Table (4):Comparison between non-problematic and potentialy problematic internet user regarding to anxiety.

\begin{tabular}{|c|c|c|c|c|c|}
\hline \multirow{2}{*}{\begin{tabular}{|l|} 
Beck depression \\
inventory
\end{tabular}} & \multicolumn{2}{|c|}{ non-problematic } & \multicolumn{2}{|c|}{ potentialy problematic } & \multirow[t]{2}{*}{ P value } \\
\hline & $\mathrm{N}=\mathbf{3 8 1}$ & Percentag \% & $\mathrm{N}=\mathbf{2 0 7}$ & Percentag\% $\%$ & \\
\hline No Depression & 216 & $56.69 \%$ & 31 & $14.98 \%$ & \\
\hline With Depression; & 165 & $43.31 \%$ & 176 & $85.02 \%$ & \\
\hline \begin{tabular}{|l} 
Mild \\
Moderate \\
Sever
\end{tabular} & $\begin{array}{l}80 \\
59 \\
26\end{array}$ & $\begin{array}{l}21.00 \% \\
15.49 \% \\
6.82 \%\end{array}$ & $\begin{array}{l}23 \\
63 \\
90\end{array}$ & $\begin{array}{l}11.11 \% \\
30.43 \% \\
43.48 \%\end{array}$ & \\
\hline
\end{tabular}

Table(5): Comparison between non-problematic and potentialy problematic internet user according to depression.

\section{DISCUSSION}

This study was conducted to assess the prevalence of PIU among undergraduate university students and to investigate some predictors of PIU and its different dimensions among the Egyptian undergraduate students. The study included 588 students, 196 student from Two practical faculities (faculty of Veterinary Medicine and faculty of Science) and 392 students from Two theoretical faculities (faculty of Arts and faculty of commerce).

In our study, prevalence rate ofPIU among students was $35.20 \%$. Our findings were consistent with the results of (IA) prevalence revealed by studies conducted in Greek $34.7 \%{ }^{[21]}$ and in Korea $38 \% \cdot{ }^{[22]}$ Our findings are also consistent with the results from other regional and international studies as those done in Palestine and

Greece which showed a prevalence of $30.1 \%$ and $34.7 \%$ respectively . ${ }^{[2,24]}$ But these findings were slightly lower than the results of two studies in Menoufia University.$^{[14,25]}$ The former found that $48.5 \%$ of medical students were pathological Internet users and the second noted that $13.2 \%$ of both medical and non medical students were problematic Internet users and $39.1 \%$ were potential problematic Internet users. The discrepancy between our findings and the results of other studies may be attributed to the unavailability of a specific definition and precise assessment of (IA), besides various 
samples and tools assigned and variation in social backgrounds.

In the present study, we found that Students of theoretical facultiessignificantly had PIU (39.29\%)thanStudents of practical faculties (27.04\%). These findings are consistent with the results of study done in Al-Azhar University, Egypt and found that the Literary colleges, were more likely to suffer more from PIU than scientific colleges ${ }^{\left[{ }^{[26]}\right.}$ Our findings are also consistent with the results from study in Menoufia University, Egypt ${ }^{[14]}$ which found that $72.5 \%$ of PIUs were from the theoretical college. Also, our findings are also consistent with the results from study in Ain shams University, Egypt $^{[27]}$ who found that the number of students with moderate to severe IA in the theoretical faculties exceeds those in the practical faculties. This marked difference could be explained by the academic overload and the high pressure of study demands in students of practical faculties. ${ }^{[28]}$

According to the age, the PIU significantly more in younger age than normal internet user. We were in line with many studies which showed that internet addiction has been reported to occur more frequently among young people.$^{[14,27,29,30]}$ Asiri et al. ${ }^{[31]}$ reported significant correlations between internet addiction and age.Fu et al. ${ }^{[32]}$ found that younger individuals used internet 3 times more than the older. This was not in agreement with lee and Stapinski ${ }^{[33]}$ who could not report a significant association between age and internet addiction.

Despite, number of female to male ratio $1: 1$, PIU was significantly more in males than in females and this was agreeable with those of most of the previous studies, suggesting that male gender is a predictor of IA . ${ }^{[24,34,35]}$ Indeed, in one study, the risk of
IA was 3.5 times higher among male students than female students ${ }^{[36]}$ In a review of IA, Chou et al. [37] concluded that male internet users were more at risk of IA owing to a stereotyped use of sexual contents; however, female users may be asymptomatic or may present limited symptoms . Also male students are more likely to become Internet dependent because they are more experienced in using the Internet, receive less parental supervision and use the Internet for entertainment purposes more than females do. ${ }^{[31]}$ However, one study found no gender differences in relation to internet addiction (IA). ${ }^{[38]}$

Regarding father job, Fathers ofPIU users significantly employed than those with non-problematic internet users. Also, PIU significantly higher in students with high monthly income in comparison with nonproblematic internet users.Because of greater opportunities to access the internet and a lack of control over their internet usage, the level of internet addiction may be high among students whose mothers and fathers are employed and among those with a high family income level. ${ }^{[39]}$ Several other researchers have reported similar results . ${ }^{[27,40]}$

We found that Students with PIU,significantly had computer and internet at home thanStudents of normal internet use. The results of our study was in line with ${ }^{[41]}$ who showed that the majority of the students had home internet access in their homes through their mobile phones and computers. Also, the same results were reported by Reda et al. ${ }^{[42]}$ among a group of Egyptian adolescents.Şaşmaz et al. ${ }^{[43]}$ revealed that the prevalence of Internet addiction was higher in students who had computer and internet access at home . 
SOHAG MEDICAL JOURNAL

Vol. 23 No.1 Jan 2019

Students with PIU, significantly used internet in chatting and games more than students with non proplematic internet use who utilized internet more for gather information and for news. This finding was consistent with previous studies showing that excessive computer/video game playing was predictive of internet addiction.$^{[3,44,45,46,47]}$ Online chatting was found to be a definite risk factor for IA in our study which was consistent with several previous studies..$^{[46,48]}$

Regarding Anxiety more than two thirds (86.9\%)of Students with PIUsignificantly had anxiety mostly with moderate to sever degree. These results were in agreement withYouneset al. ${ }^{[49]}$ who revealed a strong correlation between potential internet addiction and anxiety, stress, and depression. Previous published studies have already indicated a potential correlation between pathological internet use and anxiety ${ }^{[50]}$ Greater use of the Internet is related to declines in the size of one's social circle, loneliness,. ${ }^{[51]}$ lower selfesteem, and lower life satisfaction. ${ }^{[10]}$. Baloğlu et al. ${ }^{[52]}$ suggest that as levels of social anxiety increase and people spend less time in real-life relationships and more time on the Internet,their risk of developing PIU becomes greater.

Our study showed that more than two thirds $(85.02 \%)$ of Students with PIU significantly had Depression mostly with moderate to sever degree. Koet al. ${ }^{[10]}$ showed that Internet addiction was related positively to a decrease in social interactions, depression, loneliness and lower selfesteem .This finding is consistent with those of other studies that have found a positive relationship between depression and internet addiction. ${ }^{[53,54,55]}$ Therefore, it appears that if individuals can reduce their internet
The Relationship between Anxiety

Osama Abd Alreheem Mahmoud.et al

addiction, they may reduce their depression level $\quad{ }^{[56]}$ Previous published studies have already indicated a potential correlation between pathological internet use and depression . ${ }^{[57,58]}$

\section{LIMITATIONS:}

One of the limitations of this study is that data collection was based on selfreported questionnaires so prone to recall bias. Another limitation is being a cross-sectional study which showed the relation between PIU and some potential risk factors without being able to conclude a cause-effect relationship. So, longitudinal studies should be carried out to determine the cause-effect relationship among those variables.

\section{CONCLUSION \\ RECOMMENDATIONS:}

AND

This is one of the studies that was conducted to assess the prevalence of PIU among undergraduate university studentsin upper Egypt. Additionally, the study investigated some predictors of PIU.To conclude, in this study we found that nearly one third of the students were PIU. We showed that PIU significantly more in theoretical faculities than in practical faculities. We revealed that young age, male gender, high and moderate monthly income, presence of computer at home, Availability of internet at home, using Internet for chatting and gaming, Anxiety and depression arepredictors of PIU. We recommend that seminars, conferences and activities could be organized to highlight the negative consequences of PIU.Counseling to help the university students to learn social skills and healthier ways of coping with uncomfortable emotions, such as stress, anxiety, or depression.

\section{REFERENCES}

1.Davis, R . A cognitive-behavioral model of pathological Internet 
use. Comput HumBehav .2001; 17, 187-95.

2.Widyanto, L., \& M. G. Internet addiction: Does it really exist?(revisited). In J. Gackenbach (Ed.), Psychology and the Internet: intrapersonal, interpersonal, and transpersonal implications.2007;2, 141-63.

3.Weinstein, A., Lejoyeux, M. Internet addiction or excessive internet use. Am J Drug Alcohol Abuse.2010;36:277-283.

4.Chakraborty, K., Basu, D., Vijaya et al.Internet addiction: consensus, controversies, and the way ahead. East Asian Arch Psychiatry.2010; 20(3):123-32.

5.Kratzer, S., \&Hegerl, U. Is "Internet Addiction" a disorder of its own?-a study on subjects with excessive internet use. Psychiatry Prax.2008; $35,80-3$

6.Robin-Marie ,S. R., \&Edelmann, R. Reasons for internet use and social anxiety. PersIndiv Differ.2005;39, 949-58.

7.Yen, J., Ko, C., \& Yen, C. The comorbid psychiatric symptoms of internet addiction: attention deficit and hyperactivity disorder (ADHD), depression, social phobia, and hostility. J Adolesc Health.2007;41, 93-8.

8.DSM-IV-TR. Diagnostic and statistical manual of mental disorders. Washington, DC, APA: American

Psychiatric

Association.2000.

9.Yang, C., Choe, B., Baity, M, et al.SCL-90-R and 16PF profiles of senior high school students with excessive internet use. Can J Psychiatry.2005; 50, 407-14.

10.Ko, C. H., Yen, J. Y., Chen, C. C, et al.Gender differences and related factors affecting online gaming addiction among Taiwanese adolescents. Journal of Nervous \&
Mental Disease.2005; 193: 273277.

11.Ko, C. H., Yen, J. Y., Chen, C. S, et al .Predictive Values of Psychiatric Symptoms for Internet Addiction in Adolescents. Archives of Pediatrics and Adolescent Medicine.2009;163(10): 937-943.

12.Yen, C.F., King, B.H., \&Tang, T.C. The association between short and long nocturnal sleep durations and risky behaviours and the moderating factors in Taiwanese adolescents. Psychiatry Res .2010;179: 69-74.

13.Montag ,C., \& Reuter, M. Internet Addiction. Neuroscientific Approaches and Therapeutical Implications Including Smartphone Addiction.seconded: $\quad$ Springer International Publishing Switzerland.2017.

14.Desouky, D.A,. \&Ibrahem, R.A. Internet addiction and psychological morbidity among menoufia university students, Egypt. American Journal of Public Health Research.2015;3(5):192-8.

15.Young, K. Caught in the net: How to recognize the signs of internet addiction and a winning strategy for recovery. New York: John Wiley \& Sons. 1998.

16.Hawi ,N. S. Edcyber psychology, behavior, and social networking Mary Ann Liebert.2013; 16, 3.

17.Taylor, J."A personality scale of manifest anxiety". The Journal of Abnormal and Social Psychology.1953; 48(2): 285-290.

18.Fahmi, M., Ghali, M., \&Meleka, K. Arabic version of the personality scale of manifest anxiety, Egyptian Psychiatry.1977; 11: 119- 126.

19.Beck, A.T, \&Steer, R.A. Manual for the Beck Depression Inventory.San Antonio, TX: Psychological Corporation.1993. 
20.Abdel-Khalek, A.M. Internal consistency of an Arabic adaptation of the Beck Depression Inventory in four Arab countries. Psychol Rep.1988; 82(1):264-266.

21.Christos, C.F., Constantinos, C.F.,\& Ioannis, S. Problematic Internet Use Among Greek University Students: An Ordinal Logistic Regression with Risk Factors of Negative Psychological Beliefs, Pornographic Sites, and Online Games. Cyberpsychology, Behavior, and Social Networking.2011;14(1-2):51-8.

22.Kim, K., Ryu, E., Chon, M-Y, et al. Internet addiction in Korean adolescents and suicidal ideation: A questionnaire survey. International Journal of Nursing Studies.2006;43(2): 185-192.

23.Alhajjar, B.I. Internet addiction and psychological morbidity among nursing students in GazaPalestine. Am J Appl Psychol.2014; 3(4): 99-103.

24.Frangos, C.C., Frangos, C.C., \&Sotiropoulos, I. Problematic Internet Use among Greek university students: an ordinal logistic regression with risk factors of negative psychological beliefs, pornographic sites, and online games. CyberpsycholBehavSoc Netw. 2011; 14(1-2): 51-58.

25.Shaheen, H.M., Farahat, T.M., \& Gaber, H.M. Problematic Internet Use among Medical School Students in Menoufia University Egypt. J $\quad$ Child AdolescBehav.2016;4:298.

26.Zeinab ,E.H., Heba, M. A .,Hanaa ,A.E, et al. Problematic Internet Use Among Al-Azhar University Students in Cairo.The Egyptian Journal of Hospital Medicine .2015; 61: 535- 547.

27.ELNahas,G., $\quad$ AboElella,E., Hewedi,D, et al. Problematic Online Gaming Among a Sample of University Students in Egypt .Addict Disord Their Treatment. www.addictiondisorders.com.2018 ; 00:000-000.

28.Alavi ,S.S., Maracy, M.R., Jannatifard, F., \&Eslami, M. The effect of psychiatric symptoms on the internet addiction disorder in Isfahan's University students. J Res Med Sci .2011; 16:793-800.

29.Wang, W. Internet dependency and psychosocial maturity among college students. Int J HumanComputer Studies.2001; 55:91938.

30.Ali,Y.H.,Mohammed,A.N.,\&Ali,A .R. Internet addiction among medical students of Sohag University, Egyp. ISSN.2017;2(92) :0013-2446.

31.Asiri, S., Fallahi, F., Ghanbari, A., \&Kazemnejad-Leili,E. Internet addiction and its predictors in guilan medical sciences students. Nurs Midwifery Stud.2013; 2: 234239.

32.Fu, K.W., Chan, W.S., Wong, P.W, et al. Internet addiction: prevalence, discriminant validity and correlates among adolescents in Hong Kong. The British Journal of Psychiatry.2010; 196(6):486492.

33.Lee, B.W., \&Stapinski,L.A. Seeking safety on the internet: Relationship between social anxiety and problematic internet use. J Anxiety Disord .2012;26(1):197-205.

34.Byun, S., Ruffini, C., Mills, J.E, et al. Internet addiction: metasynthesis of 1996-2006 quantitative research. CyberpsycholBehav .2009;12:2037.

35.Tsai, H.F., Cheng, S.H., Yeh, T.L, et al. The risk factors of Internet Addiction.a survey of university freshmen. Psychiatry

Research.2009;167:294-299. 
36.Ghamari, F., Mohammad, B. A., Mohammad ,S. N.,\&Hashiani, A.A.(2011).Internet addiction and modeling its risk factors in medical students, iran. Indian J Psychol Med,33(2):158-62.

37.Chou, C ., Condron, L., \&Belland, J.C., (2005)."A Review of the Research on Internet Addiction," Educational Psychology Review, 17( 4):363-388.

38.Lam, L. T., Peng, Z. W., Mai, J. C, et al. Factors Associated with Internet Addiction among Adolescents. Cyberpsychology and Behavior.2009;12(5): 551-555.

39.Ozgul ,O., Ozlem, O., Alaettin, U. S., \&Sinan, O. Evaluation of Internet Addiction and Depression Among University Students Procedia - Social and Behavioral Sciences .2013;82 : 445 - 454.

40.Jackson, L., Alexander, E., Biocca, F, et al.Personality, cognitive style, demographic characteristics and internet use. Findings from the HomeNetToo project. Swiss Journal of Psychology.2003; 62: 79-90.

41.Saied,S.M.,Elsabagh,H.M.,\&ElAfandy,A.M. Internet and facebook addiction among Egyptian and Malaysian medical students .Int $\mathrm{J}$ Community Med Public Health.2016;3(5):12881297.

42.Reda, M., Rabie, M., Mohsen, N., \& Hassan, A. Problematic internet users and psychiatric morbidity in a sample of Egyptian adolescents. Psychology.2012;3(8):626-31.

43.Şaşmaz,T., Öner,S., Yapıcı,G, et.al. Prevalence and risk factors of Internet addiction in high school students, European Journal of Public Health.2014;24(1) : 15-20.

44.Jang, K.S., Hwang, S.Y., Choi, J.Y. Internet addiction and psychiatric symptoms among
Korean adolescents. J Sch Health.2008;78:165-171.

45.VanRooij, A.J., Schoenmakers, T.M., van de Eijnden, R.J., \& van de Mheen, D. Compulsive internet use: the role of online gaming and other internet applications. J Adolesc Health.2010;47:51-57.

46.Korkeila, J., Kaarlas, S., Jääskeläinen, M, et al. Attached to the web-harmful use of the internet and its correlates.Eur Psychiatry.2010; 25:236-241.

47.Gentile, D.A., Choo, H., Liau, A, et al. Pathological video game Use among youths: a Two-year longitudinal study. Pediatrics.2011; 127:e319-e329.

48.Van den Eijnden, R.J., Meerkerk, G.J., Vermulst, A.A, et al. Online communication, compulsive Internet use, and psychosocial wellbeing among adolescents: a longitudinal study. Dev Psychol.2008;44:655-665.

49.Younes, F., Halawi, G., Jabbour, $\mathrm{H}$, et al. Internet addiction and relationships with insomnia, anxiety, depression, stress and selfesteem in university students: A cross sectional designed study. PLoS ONE, 11: e0161126.2016.

50.Bernardi,S.,\&Pallanti, S. Internet addiction: a descriptive clinical study focusing on comorbidities and dissociative symptoms. Compr Psychiatry.2009;50(6):510-6.

51.Yang, C. K. Sociopsychiatric characteristics of adolescents who use computers to excess. ActaPsychiatrica Scandinavica.2001;104:217-222.

52.Baloğlu, M., Kozan, H.O., \&Kesici, S.Gender differences in and the relationships between social anxiety and problematic internet use: Canonical analysis. J. Med. Internet Res.2018;20: 1-9.

53.McKenna, K. Y. A., \&Bargh, J. A. Plan 9 from cyberspace: The 
implications of the Internet for personality and social psychology. Personality and Social Psychology Review.2000; 4: 57-75.

54.Kraut, R., Kiesler, S., Boneva, B, et al.Internet paradox revisited. Journal of Social Issues.2002;58: 49-74.

55.Nie, N. H., Hillygus, D. S., \&Erbring, L.Internet use, interpersonal relations, and sociability: A time diary study. In The Internet in Everyday Life;Wellman, B., Haythornthwaite, C., Eds.; Blackwell Publishers Ltd.: Oxford: UK.2002;213-243.
56.Akin, A., \&Iskender, M. Internet addiction and depression, anxiety and stress. International online journal of educational science.2011; 3(1):138-148.

57.Tsai, C.C.,\& Lin, S.S. Internet addiction of adolescents in Taiwan: an interview study. Cyberpsychol Behav.2003; 6(6):649-52.

58.Wildt, B.T., Putzig, I., Zedler, M., \&Ohlmeier, M.D.Internet dependency as a symptom of depressive mood disorders. Psychiatr Prax.34 Suppl.2007; 3:S318-22. 